\title{
6. 3 THE THREE NEW R'S FOR PROTECTED AREAS: REPURPOSE, REPOSITION AND REINVEST
}

\author{
Jamison Ervin \\ Senior Advisor, United Nations Development Programme, Waterbury, Vermont, USA, \\ jamison.ervin@undp.org
}

\begin{abstract}
There appears to be a close convergence in the international policy arena on the goals of sustainable development and biodiversity conservation, including maintaining food and water security, strengthening climate resilience, and contributing to local and national economies, among other goals. Protected area networks can help deliver on these mutual goals, but if they are to do so, we must fundamentally change how we think about protected areas, while at the same time maintaining their fundamental value in safeguarding biodiversity. This article explores how we must repurpose protected areas in order to attain not only ecological but also sustainable development goals; how we must reposition protected areas within a specific policy context in order to ensure policy relevance, including within the development of national sustainable development goals and national biodiversity plans; and how we must reinvest significant financial resources in protected areas as an economically efficient strategy for simultaneously achieving sustainable development and biodiversity conservation goals.
\end{abstract}

KEYWORDS: international protected area policy, sustainable development goals, national biodiversity plans

\section{PUNCTUATED EQUILIBRIUM AND HOT MOMENTS IN BIODIVERSITY CONSERVATION AND SUSTAINABLE DEVELOPMENT}

Social systems, like ecological systems, are often characterized by punctuated equilibrium; change is gradual, incremental and predictable, until a tipping point causes surprising, non-linear changes resulting in abrupt new states. In their analysis of policy changes, Baumgartner and Jones (2009) assert that tipping points for abrupt policy shifts typically include large-scale changes in public perception leading to a changed societal consensus; new stakeholders and audiences; new perceived social mandates; and/or major, often catastrophic, events. An example of a rapid policy shift is the raft of new US environmental policies enacted in the early 1970s, following a decade of heightened environmental awareness (Adler, 2003). Similarly, researchers recently applied the concept of punctuated equilibrium to analyse the creation of protected areas globally, and found that there are distinct 'hot moments' in time where gains in national protection occur abruptly, often within a short period of several years (Radeloff et al., 2013).
The international policy arena is now facing what appears to be a 'hot moment' related to the nexus between biodiversity conservation and sustainable development. Although the 1987 Brundtland Report on sustainable development first crystallized the notion that there are environmental limits to economic growth, and that environmental and social wellbeing are intertwined, only recently has this notion begun to take hold. There has been a critical global awareness of a series of potential tipping points for human wellbeing, including, a) major biodiversity and ecosystem losses (WWF, 2012; $\mathrm{CBD}, 2012)$; b) the economic and social consequences of these losses, particularly for the world's poorest communities (ten Brink et al., 2012); c) the limitations imposed by planetary boundaries (Rockström et al., 2009); d) the unsustainable impact of current consumption patterns (Lenzen and Murray, 2003; Lenzen et al., 2012); e) increased societal vulnerability to famine, drought, disease and natural disasters, exacerbated by biodiversity losses, war, and the impacts of climate change (UN, 2012); and f) our inability to change these trajectories with business-as-usual economic and environmental practices and policies (UN, 2012). 
Table 1: Selected contributions of protected areas to key themes in sustainable development

\begin{tabular}{|c|c|c|c|}
\hline Key theme & $\begin{array}{l}\text { Emerging themes for the } \\
\text { Sustainable Development } \\
\text { Goals (SDGs) }\end{array}$ & $\begin{array}{c}\text { Elements of the Convention } \\
\text { on Biological Diversity's } \\
\text { Strategic Plan }\end{array}$ & $\begin{array}{l}\text { Selected contribution of protected } \\
\text { area networks to SDGs and the CBD } \\
\text { Strategic Plan }\end{array}$ \\
\hline $\begin{array}{l}\text { Prevent } \\
\text { biodiversity } \\
\text { loss and } \\
\text { manage } \\
\text { resources } \\
\text { sustainably }\end{array}$ & $\begin{array}{l}\text { - Sustainably manage } \\
\text { natural resources } \\
\text { - Protect biodiversity and } \\
\text { maintain ecosystems }\end{array}$ & $\begin{array}{l}\text { - Halve the rate of loss of } \\
\text { natural habitats (Target 5) } \\
\text { - Significantly reduce habitat } \\
\text { degradation and } \\
\text { fragmentation (Target 5) } \\
\text { - Manage fisheries within } \\
\text { safe ecological limits } \\
\text { (Target 6) } \\
\text { - Prevent extinctions (Target } \\
\text { 12) }\end{array}$ & $\begin{array}{l}\text { - Maintain key habitats and refugia, } \\
\text { and ensure connectivity } \\
\text { - Prevent conversion of natural land } \\
\text { cover to other land uses } \\
\text { - Reduce habitat fragmentation } \\
\text { - Prevent overharvest of species } \\
\text { - Prevent extinctions }\end{array}$ \\
\hline $\begin{array}{l}\text { Maintain food } \\
\text { security }\end{array}$ & - Maintain food security & $\begin{array}{l}\text { - Maintain genetic diversity, } \\
\text { including of crop wild } \\
\text { relatives and domesticated } \\
\text { animals (Target 13) }\end{array}$ & $\begin{array}{l}\text { - Maintain genetic diversity, } \\
\text { including of crop wild relatives } \\
\text { - Provide a safety net in times of } \\
\text { famine }\end{array}$ \\
\hline $\begin{array}{l}\text { Maintain water } \\
\text { security }\end{array}$ & $\begin{array}{l}\text { - Ensure adequate water } \\
\text { - Ensure adequate } \\
\text { sanitation }\end{array}$ & $\begin{array}{l}\text { - Combat desertification } \\
\text { (Target 15) } \\
\text { - Restore and safeguard } \\
\text { ecosystem services related } \\
\text { to water }\end{array}$ & $\begin{array}{l}\text { - Protect watersheds } \\
\text { - Protect key water supplies } \\
\text { - Provide water filtration services }\end{array}$ \\
\hline $\begin{array}{l}\text { Strengthen } \\
\text { climate } \\
\text { resilience }\end{array}$ & $\begin{array}{l}\text { - Reduce risks and impacts } \\
\text { from climate change }\end{array}$ & $\begin{array}{l}\text { - Increase climate resilience } \\
\text { (Target 15) }\end{array}$ & $\begin{array}{l}\text { - Reduce impacts from climate- } \\
\text { related disasters }\end{array}$ \\
\hline $\begin{array}{l}\text { Improve } \\
\text { human health } \\
\text { and wellbeing }\end{array}$ & $\begin{array}{l}\text { - Address inequality and } \\
\text { poverty } \\
\text { - Secure employment, } \\
\text { livelihoods and inclusive } \\
\text { economic growth } \\
\text { - Promote health and } \\
\text { wellbeing }\end{array}$ & $\begin{array}{l}\text { - Restore and safeguard } \\
\text { ecosystem services related } \\
\text { to health, livelihoods and } \\
\text { wellbeing (Target 14) } \\
\text { - Ensure fair and equitable } \\
\text { sharing of benefits from } \\
\text { genetic resources (Nagoya } \\
\text { Protocol, Target 16) }\end{array}$ & $\begin{array}{l}\text { - Sustain livelihoods } \\
\text { - Generate employment } \\
\text { - Sustain local and national } \\
\text { economies } \\
\text { - Promote health and wellbeing } \\
\text { - Protect genetic material valuable } \\
\text { for medicines }\end{array}$ \\
\hline
\end{tabular}

Sources for emerging themes of Sustainable Development Goals: Bergh and Couturier, 2013; Cutter and Cornforth, 2013; UN, 2012. Source for CBD strategic plan: CBD, 2010. Source for protected area contributions: Kettunen, M. and P. ten Brink, 2013; Stolton and Dudley, eds., 2010)

This global awareness is reflected in the convergence of recent goals for both sustainable development, in the form of Sustainable Development Goals (SDGs), and for biodiversity conservation, in the form of the 2020 Strategic Plan for the Convention on Biological Diversity (CBD). The Sustainable Development Goals, which are the successor to the Millennium Development Goals that expire in 2015, provide the basis for countries to revise their national development plans. Based on recent analyses of early consultations on the SDGs, there is an emerging consensus around a set of key themes for the SDGs. The CBD Strategic Plan for 2020 was adopted in 2010, and virtually every country has committed to achieving an ambitious set of "Aichi Biodiversity Targets," and revising their National Biodiversity Strategies and Action Plans (NBSAPs) in accordance with these targets (CBD, 2010). See Table 1 for a summary of these goals.
At the same time, there is growing global consensus that many of the pressing issues in sustainable development and biodiversity conservation - preventing biodiversity losses and managing natural resources sustainably, maintaining food and water security, reducing risks from natural disasters, strengthening climate resilience and improving human health and wellbeing - can be at least partially addressed by comprehensive, well-managed protected area networks (Kettunen, M. and P. ten Brink, 2013; Stolton and Dudley, eds., 2010). Table 1 shows the relationship between the key emerging themes in the SDG development process, the themes embedded within the CBD Strategic Plan, and the contribution of protected areas to each of these themes.

Protected areas clearly have a role in contributing to the emerging key themes of sustainable development in this 'hot moment' in history. Yet the global business-as-usual 
Table 2: Repurposing protected areas to achieve sustainable development goals

\begin{tabular}{|c|c|c|}
\hline $\begin{array}{l}\text { Actions related to } \\
\text { protected areas }\end{array}$ & $\begin{array}{l}\text { Current framework - } \\
\text { protected areas for } \\
\text { biodiversity conservation }\end{array}$ & $\begin{array}{l}\text { Emerging framework - protected areas for biodiversity } \\
\text { conservation and sustainable development }\end{array}$ \\
\hline $\begin{array}{l}\text { Establishing } \\
\text { protected areas }\end{array}$ & $\begin{array}{l}\text { Protected areas are } \\
\text { established primarily to fill } \\
\text { ecological gaps, and to } \\
\text { protect rare and } \\
\text { endangered species and } \\
\text { their habitats. }\end{array}$ & $\begin{array}{l}\text { Protected areas are established to achieve multiple } \\
\text { societal goals simultaneously, including ecological, social } \\
\text { and economic goals. This may mean, for example, } \\
\text { including overlays of ecosystem services as part of } \\
\text { ecological gap analyses, and explicitly establishing } \\
\text { protected areas for social and economic benefits, such } \\
\text { as for protecting genetic stocks of crop wild relatives. }\end{array}$ \\
\hline $\begin{array}{l}\text { Managing protected } \\
\text { areas }\end{array}$ & $\begin{array}{l}\text { Protected areas are } \\
\text { managed primarily for } \\
\text { biodiversity conservation } \\
\text { goals, with some additional } \\
\text { social benefits. }\end{array}$ & $\begin{array}{l}\text { Protected areas are managed for multiple benefits, such } \\
\text { as maintaining water supplies during times of drought, } \\
\text { providing sustainable livelihoods to local communities, } \\
\text { and generating revenue through increased tourism. This } \\
\text { will require a more concerted, systematic assessment of } \\
\text { potential trade-offs between ecological, social and } \\
\text { economic benefits and the development of social and } \\
\text { ecological safeguards. }\end{array}$ \\
\hline $\begin{array}{l}\text { Communicating with } \\
\text { stakeholders }\end{array}$ & $\begin{array}{l}\text { Protected area stakeholders } \\
\text { are mostly viewed as local } \\
\text { communities, who may see } \\
\text { an increase or decrease in } \\
\text { benefits. }\end{array}$ & $\begin{array}{l}\text { Protected areas managed for multiple benefits are likely } \\
\text { to include a much broader array of stakeholders, } \\
\text { including, for example, national stakeholders involved in } \\
\text { water, food, tourism, health, disaster prevention and } \\
\text { development, among others. }\end{array}$ \\
\hline $\begin{array}{l}\text { Assessing } \\
\text { effectiveness }\end{array}$ & $\begin{array}{l}\text { Protected areas are } \\
\text { assessed primarily for their } \\
\text { effectiveness in achieving } \\
\text { ecological outcomes. }\end{array}$ & $\begin{array}{l}\text { Protected areas are assessed relative to their delivery of } \\
\text { a range of benefits, including social and economic } \\
\text { benefits. As countries invest in protected areas as an } \\
\text { economic development strategy, they will increasingly } \\
\text { want to assess their economic return on investment and } \\
\text { to gauge the delivery of benefits. }\end{array}$ \\
\hline Monitoring change & $\begin{array}{l}\text { Protected area monitoring } \\
\text { focuses primarily on the } \\
\text { status and trends of threats } \\
\text { and biodiversity. }\end{array}$ & $\begin{array}{l}\text { Protected areas will increasingly be monitored against } \\
\text { social and ecological safeguards, as well as ecological } \\
\text { tipping points and thresholds, in order to ensure that } \\
\text { the delivery of social or economic benefits does not } \\
\text { erode ecological health and integrity. }\end{array}$ \\
\hline
\end{tabular}

scenario for many protected areas must change, if protected areas are to fully deliver on their potential. Traditionally, protected areas face three challenges. The first is inadequate design and management of the protected area network - protected area networks often contain too small, too few and too isolated protected areas, with major gaps in biodiversity representativeness, and there are often chronic problems with effective management, including inadequate staffing, management plans, threat abatement efforts, monitoring and communication (Bertzy et al., 2012). The second challenge is that protected areas are not fully integrated into broad policy frameworks, and are often viewed as isolated land and sea uses (Ervin et al., 2010a). The third challenge is insufficient funding, even for minimal management needs (Bovarnick et al., 2012).

If protected areas are to both overcome these challenges and address emerging goals for both sustainable development and biodiversity conservation, we must fundamentally change how we think about protected areas. We must repurpose protected areas to attain not 


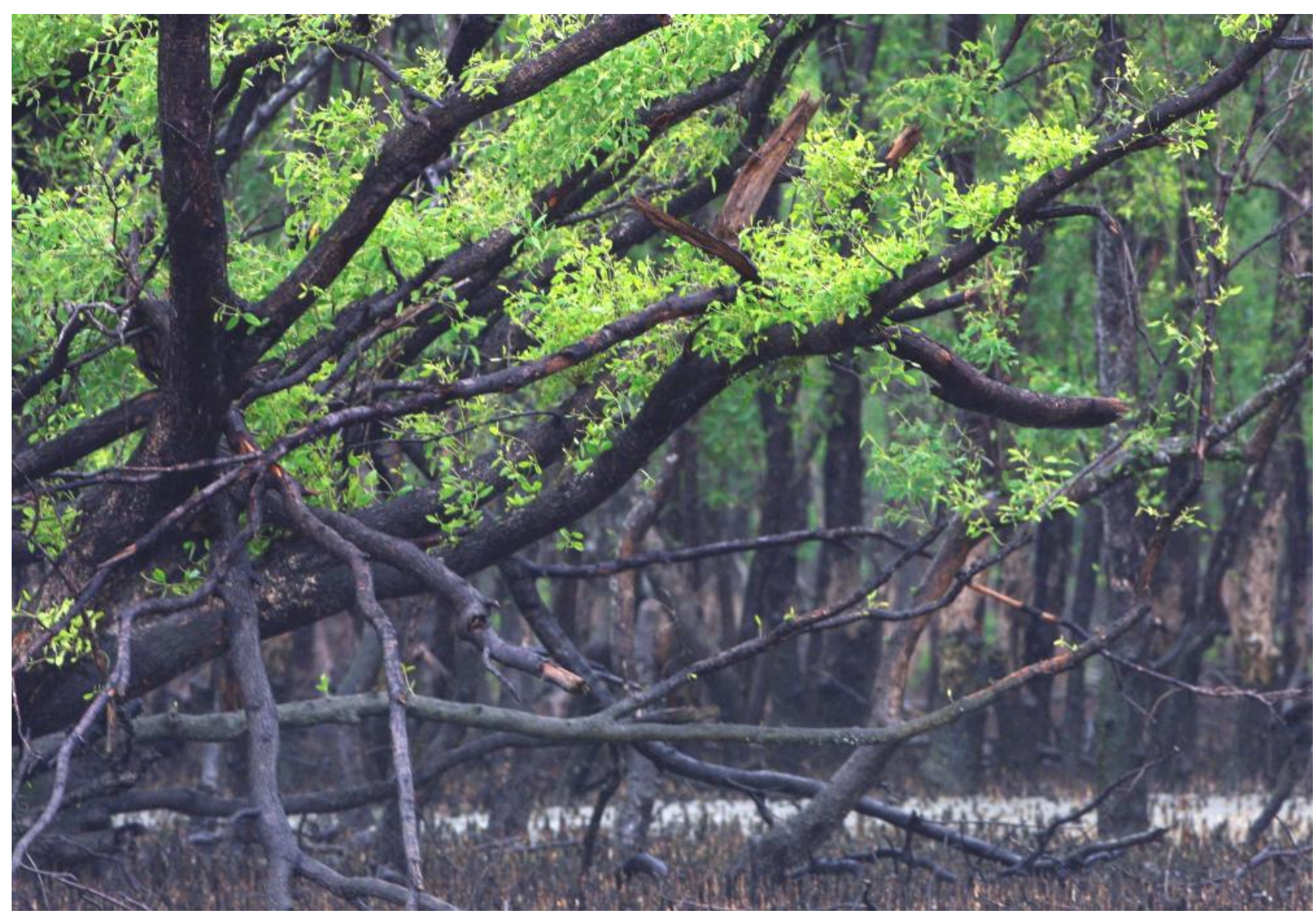

Mangroves help mitigate the impacts of storm surges, Sundarbans National Park, Bangladesh @ David Woodfall / WWF-UK

only ecological but also sustainable development goals, reposition protected areas within a specific policy context in order to ensure policy relevance, and reinvest in protected areas as an economically efficient strategy for simultaneously achieving sustainable development and biodiversity conservation goals.

\section{REPURPOSE PROTECTED AREAS TO CONTRIBUTE TO BOTH BIODIVERSITY CONSERVATION AND SUSTAINABLE DEVELOPMENT GOALS}

There have been several shifts in the way that society has envisioned protected areas over the past 150 years, from a classic model in the 1800 s through the 1970s, where protected areas were established and managed for scenic and recreational values; and from a modern model from the 1970 s through the mid-20oos where protected areas were established and managed for scientific, economic and cultural reasons, to an emerging model where protected areas are expected to maintain critical life support services and contribute to sustainable development (Ervin et al., 2010). Never have we expected more from protected areas, and never have the stakes been higher for protected areas to fully deliver a wider range of social, economic and ecological benefits. In addition to conserving biodiversity, protected areas must now also provide jobs and livelihoods, drive economic growth, safeguard wild crop relatives, protect and maintain key ecosystem services, and buffer humanity from the worst of climate change impacts. Therefore, we must rethink how new protected areas are established, and repurpose existing protected areas, including how they are managed, communicated, assessed and monitored, if protected areas are to fully contribute to sustainable development goals (see Table 2).

\section{REPOSITIONING PROTECTED AREAS WITHIN SPECIFIC ECONOMIC AND DEVELOPMENT POLICIES TO ENSURE POLICY RELEVANCE}

If protected areas are to help achieve sustainable development goals, the second task will be to reposition them within specific economic and development policies and policy frameworks, in order to ensure policy relevance. In most countries, protected areas are positioned within a national ministry of environment, natural resources, wildlife, fisheries or forestry. As a result, they are often viewed as a distinct and isolated land use, completely separate from other economic and social land uses in the surrounding landscape and seascape, and are rarely positioned within specific economic and development policies (Mose, 2011; Ervin et al., 2010). There are two specific planning opportunities where protected areas can be better repositioned within 
the policy landscape, to capitalize on their social and economic contributions: 1) the revision of national sustainable development strategies (SDGs), and 2) the revision of National Biodiversity Strategies and Action Plans (NBSAPs).

Repositioning protected areas within national sustainable development strategies and plans

Following the publication of "Our Common Future" (WCED, 1987), the global community embraced the idea of sustainable development as an organizing framework for developing national development goals. In 1992, the Rio Earth Summit resulted in Agenda 21, with global consensus that all countries should develop a national sustainable development strategy. This call was repeated at the World Summit on Sustainable Development a decade later, and most recently at Rio+ 20 in 2012. Now more than 100 countries have developed national sustainable development plans and goals. However, of the 72 national sustainable development reports listed on the United Nations Sustainable Development website, fewer than a dozen specifically mention protected areas in their national sustainable development reports ${ }^{1}$, and of these, only a handful clearly show the contributions that protected areas can make in achieving national sustainable development goals. If protected area policy makers are to ensure that protected areas are relevant to national sustainable development planning, they must understand how to reposition protected areas as clearly delivering on sustainable development goals. This may include, for example, demonstrating how protected areas can:

- Enhance national food and water security: Lao PDR, for example, clearly links protected areas, nontimber forest products and national food security in its Fourth National Report (Government of Lao PDR, 2010), and links protected areas to water security in both its Water Sector Strategy and Action Plan as well as in its National Report on Protected Areas and Development (ICEM, 2011).

- Secure employment and livelihoods: Botswana clearly links local income generation from tourism within protected areas (Government of Botswana, 2012), South Africa's "Working for Water" program links job creation, ecosystem services protection and restoration of protected areas (DWA, 2013), and a new collection of studies shows how protected areas can drive regional economic development across Europe (Mose, 2011).

- Buffer vulnerable communities from disasters: Both Moldova (Government of Moldova, 2012) and the South Africa (DEA, 2011) identify protected areas as a key strategy to strengthen resilience to climate impacts and natural disaster risk reduction.

- Foster healthy populations: Parks Victoria's Healthy People Healthy Parks Initiative highlights the many health benefits that protected areas provide to communities (Parks Victoria, 2013).

- Reduce border-related conflicts: Transboundary protected areas have been clearly linked with reducing border-related conflicts (Sandwith et al., 2001). Timor Leste, for example, links protected areas and nature conservation to conflict prevention in its national report on sustainable development (MED, 2012).

These examples illustrate just a few of the ways that policy makers can reposition protected areas within national sustainable development goals in order to ensure national relevance beyond biodiversity conservation.

\section{Repositioning protected areas within National} Biodiversity Strategies and Action Plans (NBSAPs) National Biodiversity Strategies and Action Plans (NBSAPs) are the primary national instruments for implementing the Convention on Biological Diversity, and are required by all signatories (CBD, 2010). To date, 178 countries have completed an NBSAP, and nearly all countries are in the process of revising their NBSAPs to be in accordance with the Aichi Biodiversity Targets by 2015. This represents an unprecedented opportunity to reposition protected areas within broader conservation and development goals for a decade or more. While the vast number of NBSAPs submitted to date include a section or chapter on protected areas (Prip and Gross, 2010), very few of these plans clearly show specifically how protected areas can contribute to a broader range of economic and development goals. Yet, as shown in Table 1, protected areas can contribute to a number of Aichi Biodiversity Targets (including Targets 5,6,11, 12, 13, 14, 15 and 16), many of which relate directly to sustainable development goals.

Instead of developing separate chapters that simply catalogue their existing and planned protected area network, national planners developing their NBSAPs can ensure that protected areas are properly positioned within their NBSAPs by taking the following actions:

- Position protected areas at the centre of NBSAPs instead of the periphery: Given their disproportionate role in simultaneously achieving ecological, social and economic goals, as well as achieving multiple Aichi Biodiversity Targets, 
protected areas should feature prominently within NBSAPs as an organizing framework, rather than as an isolated section or chapter. More than 100 countries have developed detailed national plans for implementing the CBD Programme of Work on Protected Areas (CBD, 2013), and these plans can provide a strong core for the NBSAP.

- Position protected areas within different ministries: In the vast majority of countries, protected area agencies fall solely within the confines of environmental ministries, without crosspollination with other related ministries. As they develop their biodiversity and sustainable development plans and goals, countries may want to consider formal linkages between protected area agencies and those agencies and ministries related to economic and social development, such as tourism, water and sanitation, and land use planning.

- Articulate the many values and benefits of protected areas: Planners should clearly articulate the many values and benefits of protected areas, including the social and economic benefits related to sustainable development. In doing so, they help lay the foundation for making the economic case for further investments in the protected area network.

- Link the establishment of new protected areas to multiple goals and targets: Most NBSAPs identify the need for new protected areas, but nearly all do so solely within a biodiversity conservation framework without linking to social or economic benefits. In order to achieve the Aichi Targets, approximately 5.5 million $\mathrm{km}^{2}$ of new terrestrial and 10.8 million $\mathrm{km}^{2}$ of new marine protected areas will need to be established globally (Ervin and Gidda, 2012). To fully capitalize on the potential multiple contributions that these new protected areas can make, planners should explicitly link the establishment of new protected areas not only to ecological goals (e.g., decreasing habitat fragmentation, preventing extinctions), but also to social and economic goals (e.g., strengthening national food and water security; safeguarding genetic resources for wild crop relatives; securing sustainable livelihoods; and strengthening resilience to floods, droughts, storms and natural disasters).

By repositioning protected areas within national sustainable development goals and plans, and within broader national biodiversity plans, policy makers can ensure that protected areas are viewed not only as a strategy for conserving biodiversity, but also as a strategy for achieving broader national goals and objectives.

\section{REINVESTING IN PROTECTED AREAS AS AN} EFFECTIVE, EFFICIENT STRATEGY FOR ACHIEVING SUSTAINABLE DEVELOPMENT GOALS

The third task required of policy makers for helping protected areas deliver on sustainable development goals is to reinvest in protected areas themselves. The current global protected area estate covers nearly 13 per cent of the world's terrestrial area (Bertzky et al., 2012), representing an unprecedented global investment in biodiversity conservation in the form of acquisition costs, lost opportunity costs for other forms of economic activity, and ongoing management costs. Yet there remain significant gaps in the total protected area finance requirements, estimated at approximately US $\$ 34$ billion annually (Ervin and Gidda, 2012). Compared with this figure, the current levels of official development assistance for protected areas ${ }^{2}$ is but a tiny fraction, while governments currently provide on average less than half of the finance required (Bovarnick et al., 2010). Simply put, countries themselves will need to reinvest in protected areas, and if protected areas are to receive adequate funding to fully deliver on increased expectations, they will need to compete with other forms of societal investment. However, it is likely that by any estimate, protected areas will compete well as an efficient, cost-effective investment strategy; citing numerous cases, one study estimates the economic return on investments on protected areas of between 1:25 and 1:100 (ten Brink, 2012).

To reinvest in protected areas, policy makers will need to shift how they think about protected area finance, including by taking the following actions:

- Calculate the full costs and benefits of protected areas: The overwhelming majority of NBSAPs over the past decade did not identify the specific costs associated with the strategies and plans (Prip and Gross, 2010), including for protected areas. Planners must lay out the full range of costs associated with implementing protected area strategies, including establishment and management of protected areas that address additional societal goals. In order to understand the potential development and economic return on investment in protected areas, planners will need to understand both the full short-term and long-term costs and benefits, and the likely distribution of those benefits.

- Undertake a protected area expenditure review: By analysing what is currently being spent by both public and private actors, planners can better understand the incremental costs required for further investment, and better evaluate the benefits against other forms of investment. 


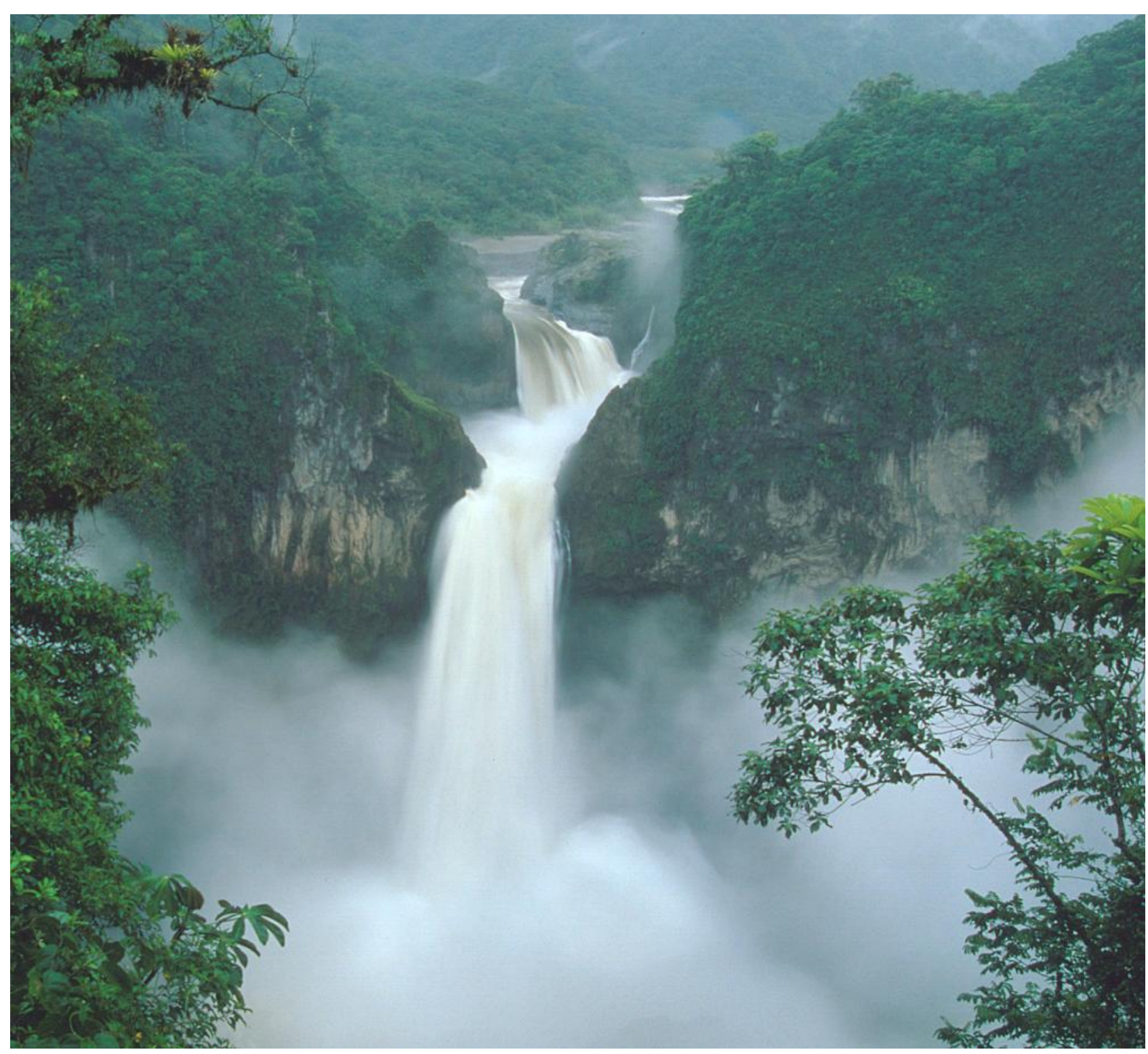

About $\mathbf{8 0}$ per cent of the $\mathbf{1 . 5}$ million population of the capital of Ecuador population receive drinking water from two protected areas: Antisana and Cayambe-Coca Ecological Reserve (pictured here) @ Kevin Schafer / WWF-Canon

- Review and remove harmful policies and instruments: There are a wide number of perverse subsidies and incentives that harm biodiversity in general, and protected areas in particular (CBD, 2011). Reviewing, and where appropriate removing, these policies can not only reduce pressures on protected areas, but also unlock finance to fill critical resource gaps.

- Develop a resource mobilization plan for protected areas: A resource mobilization plan can help planners develop a financial road map for fully investing in protected areas. By linking the costs of protected areas to the multiple benefits, planners can tap new finance streams, such as insurance companies, national defence budgets, agricultural companies who rely on pollinators and irrigation, municipal drinking water budgets and other sources.
By treating protected areas as an investment vehicle, policy makers will be better able to unlock and mobilize the financial resources required to enable protected areas to fully deliver on their potential.

\section{CONCLUSION}

It is clear that this is a potentially 'hot moment' for the convergence of biodiversity conservation and sustainable development goals. There is widespread recognition that the current trajectories of economic development and biodiversity loss are unsustainable, and that biodiversity conservation in general, and protected areas in particular, stand as one of the most efficient and costeffective strategies for simultaneously changing both of these trajectories. No discussion about the changing role of protected areas is complete, however, without acknowledging that repurposing, repositioning and 
reinvesting in protected areas may require new tradeoffs, and this will require a more deliberate and conscious application of social and ecological safeguards. This debate is already fully underway (Minteer and Miller, 2011; McShane et al., 2011; Redpath et al., 2013), and there is already emerging guidance for key sectors, such as tourism (Drumm et al., 2011), but practical guidance and global consensus will need to mature quickly to keep pace with global policy trends.

Protected area policy makers must now make concerted efforts to repurpose protected areas to deliver on both biodiversity and sustainable development goals, to reposition protected areas within national economic and development policies and planning frameworks, to reinvest in protected areas as a viable, economic strategy, and to ensure critical safeguards for doing so. Only then with this hot moment in history truly take hold.

\section{ENDNOTES}

1. See sustainabledevelopment.un.org/ rio2onationalreports.html (Accessed October 1, 2013). 2. For example, the Global Environmental Facility, the largest source of Official Development Assistance, allocated about US\$700 million over four years for all of its global work on protected areas.

\section{ABOUT THE AUTHOR}

Jamison Ervin is Senior Advisor with the United Nations Development Programme. She also serves on the IUCN World Commission on Protected Areas Task Force on Capacity. Her work focuses primarily on protected area planning and management, national biodiversity planning and finance, and the development of e-learning modules for practitioners.

\section{REFERENCES}

Adley, J. 2003. Fables of the Cuyahoga: Reconstructing a history of environmental protection. Fordham Environmental Law Journal (14): 89-147. http:// law.cwru.edu/faculty/adler_jonathan/publications/ fables_of_the_cuyahoga.pdf

Baumgartner, F.R. and B. D. JoneS. 2009. Agendas and Instability in American Politics. Chicago: University of Chicago Press.

Bergh, G. and J. Couturier. 2013. What do we know about the world's proposals for post-2015 goals? Overseas Development Institute. Available at: http:// post2015.org/2013/05/16/what-do-we-know-about-theworlds-proposals-for-post-2015-goals-first-analysis-fromthe-future-goals-tracker/

Bertzky, B., C. Corrigan, J. Kemsey, S. Kenney, C. Ravilious, C Besançon and N. Burgess. 2012. Protected Planet Report 2012: Tracking progress towards global targets for protected areas. IUCN, Gland, Switzerland and UNEPWCMC, Cambridge, UK. Available at: http://www.unep- wcmc.org/medialibrary/2012/09/14/eb3bb854/ PPR2012_en.pdf

Bovarnick, A., J. Fernandez Baca, J. Galindo, and H. Negret. 2010. Financial Sustainability of Protected Areas in Latin America and the Caribbean: Investment Policy Guidance. New York: United Nations Development Programme (UNDP) and The Nature Conservancy (TNC). Available at: http://www.undp.org/content/dam/aplaws/publication/ en/publications/environment-energy/www-ee-library/ biodiversity/financial-sustainability-of-protected-areas-inlatin-america-and-the-caribbean/financial_sus_pa_lac.pdf

CBD. 2010. Convention on Biological Diversity's Strategic Plan for 2020. Montreal: CBD. Available at: www.cbd.int/sp.

$\mathrm{CBD}$. 2011. Incentive Measures for the Conservation and Sustainable Use of Biological Diversity: Case Studies and Lessons Learned. CBD Technical Series No. 56. Montreal: Secretariat of the Convention on Biological Diversity. Available at: http://www.cbd.int/doc/publications/cbd-ts56-en.pdf

CBD. 2012. Resourcing the Aichi Biodiversity Targets: A first assessment of the resources required for implementing the strategic plan for biodiversity. Montreal: CBD Secretariat. Available at: http://www.cbd.int/doc/meetings/fin/hlpgar -sp-01/official/hlpgar-sp-01-01-report-en.pdf

CBD, 2013. National Action Plans for implementing the Programme of Work on Protected Areas (website). http:// www.cbd.int/protected/implementation/actionplans/, accessed October 1, 2013.

Cutter, A. and J. Cornforth. 2013. Initial stocktaking analysis of the SDGs e-Inventory: Visions for global goals. Available at: http://www.sustainabledevelopment2015.org/

Department of Environmental Affairs. 2011. National Strategy for Sustainable Development and Action Plan (NSSD 1) 2011-2014. Johannesburg: Department of Environmental Affairs, South Africa. Available at: https:// www.environment.gov.za/sites/default/files/docs/ sustainabledevelopment_actionplan_strategy.pdf

Department of Water Affairs. 2013. Working for Water (website). Johannesburg: Department of Water Affairs. http://www.dwaf.gov.za/wfw/, accessed October 1, 2013.

Drumm, A., S. McCool, and J. Rieger. 2011. The Threshold of Sustainability for Tourism within Protected Areas: a Quick Guide for Protected Area Practitioners. Protected Area Quick Guide Series Editor, J. Ervin. Arlington, VA: The Nature Conservancy. Available at: http:// conservationfinance.org/upload/library/ arquivo20120410174958.pdf

Ervin, J. and S. Gidda. 2012. Input to the Report of the HighLevel Panel on Global Assessment of Resources for Implementing the Strategic Plan for Biodiversity 2011 2020: Target 11. Available at: http://www.cbd.int/doc/ meetings/fin/hlpgar-sp-01/official/hlpgar-sp-01-08-en.pdf

Ervin, J., K. J. Mulongoy, K. Lawrence, E. Game, D. Sheppard, P. Bridgewater, G. Bennett, S.B. Gidda. and P. Bos. 2010a. Making Protected Areas Relevant: A guide to integrating protected areas into wider landscapes, seascapes and sectoral plans and strategies. CBD Technical Series No. 44. Montreal. Available at: www.cbd.int/doc/publications/cbd -ts-44-en.pdf

Ervin, J., N. Sekhran, A. Dinu, S. Gidda, M. Vergeichik and J. Mee. 2010b. Protected Areas for the $21^{\text {st }}$ Century: Lessons from UNDP/GEF's Portfolio. New York: United Nations Development Programme and Montreal: Convention on Biological Diversity. Available at: www.cbd.int/cms/ui/ forums/attachment. aspx?id=89 
Government of Botswana. 2012. Botswana National Report for the United Nations Conference on Sustainable Development. Available at: http:// sustainabledevelopment.un.org/content/ documents/1006 National\%20Report\%20-\% 20Botswana.pdfhttp://sustainabledevelopment.un.org/ content/documents/1006National\%20Report\%20-\% 20Botswana.pdf

Government of Lao PDR. 2010. Lao People's Democratic Republic: Fourth National Report to the Convention on Biological Diversity. Available at: http://www.cbd.int/doc/ world/la/la-nr-04-en.pdf

Government of the Republic of Moldova. 2012. National Report for UN CSD 2012 Rio+20. Available at: http:// sustainabledevelopment.un.org/content/ documents/782Moldova_Report_RIO20_ENG_12-062012_final.pdf.

ICEM, 2003. Lao PDR National Report on Protected Areas and Development: Review of Protected Areas and Development in the Lower Mekong River Region, Indooroopilly, Queensland, Australia. 101 pp. Available at: http://www.mekong-protected-areas.org/lao_pdr/docs/ lao_pdr_nr.pdf

Kettunen, M. and P. ten Brink, eds. 2013. Social and Economic Benefits of Protected Areas: An Assessment Guide. London: Earthscan.

Lenzen, M. and S.A. Murray. 2003. The Ecological Footprint Issues and Trends. Sydney: University of Sydney. Available at: http://www.see-change.org.au/sites/default/files/ Ecological_Footprint_Issues_and_Trends.pdf

Lenzen, M., K. Kanemoto, D. Moran and A. Geschke. 2012. Mapping the Structure of the World Economy. Environmental Science and Technology, 46: 8374-8381.

McShane, T.O., P.D. Hirsch, T.C. Trung, A.N. Songorwa, A. Kinzig, B. Monteferri, D. Mutekanga, H. van Thang, J.L. Dammert, M. Pulgar-Vidal, M. Welch-Devine, J.P. Brosius, P. Coppolillo and S. O'Connor. 2011. Hard Choices: Making trade-offs between biodiversity conservation and human well-being. Biological Conservation 144: 966-972.

Ministry of Economy and Development. 2012. Sustainable Development in Timor-Leste; National Report to the United Nations Conference on Sustainable Development. Available at: http://sustainabledevelopment.un.org/ content/documents/978timor.pdf

Minteer, B.A. and T. R. Miller. 2011. The New Conservation Debate: Ethical foundations, strategic trade-offs and policy opportunities. Biological Conservation 144: 945947.

Mose, I. 2011. Protected Areas and Regional Development in Europe: Towards a New Model for the 21st Century. Surrey: Ashgate Publishing.

OECD. 2006. Good Practices in the National Sustainable Development Strategies of OECD Countries. Paris: OECD. Available at: http://www.oecd.org/ greengrowth/36655769.pdf

Parks Victoria. 2013. Healthy Parks Healthy People (website). Victoria: Parks Victoria. http://parkweb.vic.gov.au/, accessed October 1, 2013.

Prip, C. and T. Gross. 2010. Biodiversity Planning: An assessment of national biodiversity strategies and action plans. Tokyo: United Nations University. Available at: http://www.ias.unu.edu/resource_centre/UNUIAS_Biodiversity_Planning_NBSAPs_Assessment_final_we b_Oct_2010.pdf.
Radeloff, V. C., Beaudry, F., Brooks, T. M., Butsic, V., Dubinin, M., Kuemmerle, T. and Pidgeon, A. M.. 2013. Hot moments for biodiversity conservation. Conservation Letters, 6: 58-65. doi: 10.1111/j.1755-263X.2012.00290.x

Redpath, S.M., J. Young, A. Evely, W.M. Adams, W.J. Sutherland, A. Whitehouse, A. Amar, R.A. Lambert, J.D.C Linnell, A. Watt and R.J. Gutiérrez. 2013. Understanding and managing conservation conflicts. Trends in Ecology and Evolution 28(2): 100 - 109.

Rockström, J. et al. 2009. Planetary boundaries: exploring the safe operating space for humanity. Ecology and Society, 14(2).

Sandwith, T., C. Shine, L. Hamilton and D. Sheppard. 2001, Transboundary Protected Areas for Peace and Cooperation. Gland, Switzerland: IUCN. Available at: iucn.org/dbtw-wpd/edocs/PAG-007.pdf

Stolton, S. and N. Dudley, eds. 2010. Arguments for Protected Areas: Multiple Benefits for Conservation and Use. London: Earthscan.

ten Brink P., Mazza L., Badura T., Kettunen M. and Withana S. 2012. Nature and its Role in the Transition to a Green Economy. United Nations Environment Programme - The Economics of Ecosystems and Biodiversity. Available at: www.teebweb.org.

UN System Task Team on the Post-2015 UN Development Agenda. 2012. Realizing the Future We Want for All: Report to the Secretary-General. New York: United Nations. Available at: http:// sustainabledevelopment.un.org/content/ documents/614Post_2015_UNTTreport.pdf

UNEP. 2010. The Economics of Ecosystems and Biodiversity: TEEB for Policy Makers. Nairobi: UNEP. Available at: http://www.teebweb.org/our-publications/allpublications-2/\#.UjCWejasjlU

United Nations. 1987. United Nations. 1987. Report of the World Commission on Environment and Development, General Assembly Resolution 42/187, 11 December 1987. Available at: http://www.un.org/documents/ga/res/42/ ares42-187.htm

United Nations. 2013. Global Sustainable Development Report - Executive Summary: Building the Common Future We Want. New York: United Nations Department of Economic and Social Affairs, Division for SustainableDevelopment. 2013, http://sustainabledevelopment.un.org/ globalsdreport/

WWF. 2012. Living Planet Report. Gland, Switzerland: WWF. Available at: http://awsassets.panda.org/ downloads/1_Ipr_2012_online_full_size_single_pages_fin al_120516.pdf 


\section{RESUMEN}

Parece haber una gran convergencia en el escenario de la política internacional con respecto a los objetivos de desarrollo sostenible y la conservación de la biodiversidad, incluyendo la preservación de la seguridad hídrica y alimentaria, el fortalecimiento de la adaptación al cambio climático, y la contribución a las economías locales y nacionales, entre otros objetivos. Las redes de áreas protegidas pueden ayudar al logro de estos objetivos comunes, pero para ello debemos cambiar fundamentalmente nuestra forma de pensar con respecto a las áreas protegidas, manteniendo al mismo tiempo su valor primordial en la protección de la biodiversidad. Este artículo explora cómo debemos replantear las áreas protegidas con el fin de alcanzar no solo los objetivos ecológicos sino también los de desarrollo sostenible; cómo debemos reorganizar las áreas protegidas dentro de un contexto político específico para garantizar la pertinencia de las políticas, incluso dentro de la definición de las metas nacionales de desarrollo sostenible y los planes nacionales sobre biodiversidad; y cómo debemos reinvertir cuantiosos recursos financieros en las áreas protegidas como estrategia económicamente eficiente para lograr de manera simultánea los objetivos de desarrollo sostenible y de conservación de la biodiversidad .

\section{RÉSUMÉ}

Il semble qu'il y ait une étroite convergence sur la scène politique internationale entre les objectifs du développement durable et ceux de la conservation de la biodiversité, autour notamment des points suivants : préservation de la sécurité alimentaire et de l'approvisionnement en eau, renforcement de la résilience du climat, et contribution aux économies nationales et locales. Les réseaux d'aires protégées peuvent permettre de réaliser ces objectifs mutuels, mais dans ce cas, nous devons fondamentalement changer notre façon de considérer les aires protégées tout en préservant leur valeur fondamentale pour la préservation de la biodiversité. Cet article s'interroge sur les façons de réadapter les aires protégées afin d'atteindre des objectifs de développement écologiques, mais également durables; de repositionner les aires protégées dans un contexte politique spécifique afin de garantir leur pertinence politique, notamment avec la mise en place des objectifs nationaux de développement durable et les plans nationaux de préservation de la biodiversité; et de réinvestir des ressources financières significatives dans les aires protégées, dans le cadre d'une stratégie économiquement efficace qui permette d'atteindre en même temps les objectifs de conservation pour le développement durable et pour la biodiversité. 